Article

\title{
Flood Effect on Groundwater Recharge on a Typical Silt Loam Soil
}

\author{
Guohua Zhang ${ }^{1}$, Gary Feng ${ }^{2}$, Xinhu $\mathrm{Li}^{3}{ }^{3}{ }^{*}$, Congbao Xie ${ }^{1}$ and Xiaoyu $\mathrm{Pi}^{4}$ \\ 1 China Irrigation and Drainage Development Center, Beijing 210054, China; zgh311133@163.com (G.Z.); \\ xchb@263.net (C.X.) \\ 2 USDA-Agricultural Research Service, Starkville, MS 39762, USA; Gary.Feng@ARS.USDA.GOV \\ 3 State Key Laboratory of Desert and Oasis Ecology, Xinjiang Institute of Ecology and Geography, \\ Chinese Academy of Sciences, Urumqi 830011, Xinjiang, China \\ 4 The Water Service Bureau of Chaoyang of Beijing City, Beijing 100026, China; zgh2pxy@163.com \\ * Correspondence: lixinhu@ms.xjb.ac.cn; Tel.: +86-099-1788-5428
}

Received: 30 March 2017; Accepted: 10 July 2017; Published: 14 July 2017

\begin{abstract}
Floods are of great concern as the global climate changes, and investigations of flood water infiltration and groundwater recharge are important for water resource management worldwide, especially under conditions of global climate changes. However, information on the relationship between the flood water and groundwater recharge is limited. The objective of this study was to determine the relationship between the flood water depth and the height of groundwater rise using lysimeters and numerical modeling in the floodplain of the Tarim River in northwestern China. The experimental results suggested that the rise in height of the groundwater table was closely related to the flood water ponding depth, and the groundwater depth decreased quickly after flooding due to the high infiltration rate of water originating at the Tarim River. The water table falling velocity was significantly less than the water table rising velocity. If the initial groundwater table was deeper, the variation in the water table rise depth was smaller and the water table falling velocity was slower. The numerical simulation results showed good agreement with the observed data, with a determination coefficient $\left(R^{2}\right)$ of 0.87 and a root mean square error (RMSE) of $63.91 \mathrm{~cm}$. A good relationship $\left(R^{2}=0.789\right)$ between the initial groundwater table depth $\left(H_{0}\right)$, initial soil water content $\left(W_{0}\right)$, flood water depth $(h)$, and height of the water table rise $(H)$ was established. Considering that natural and artificial flood frequencies are related to flood time interval $(d t)$, a relationship $\left(R^{2}=0.892\right)$ was developed between them. These results can enhance the understanding of flood recharge characteristics in the floodplains of inland rivers.
\end{abstract}

Keywords: arid land; flood; groundwater recharge; inland river; lysimeter

\section{Introduction}

Floods are important sources of groundwater recharge in most of the world's arid lands [1]. With appropriate management practices, floods can benefit the ecology of arid and semi-arid areas [2]. Flood spreading (due to river overflows) is one of the methods used for flood management and water harvesting that increases the groundwater recharge [3]. Recharge is the portion of infiltration that reaches the water table after passing through the soil profile [4]. In arid environments, stream beds of ephemeral rivers are largely composed of permeable, coarse alluvial sediments that promote relatively rapid infiltration of flood water, which then recharges the local alluvial aquifers [5]. Several methods including direct observation [5,6], mathematical modeling [7], and stable isotope studies [8,9] have been used to estimate flood water infiltration and groundwater recharge.

Groundwater is an important source of water for the growth of natural vegetation in arid and semi-arid areas [10]. As drought, climate change, and increasing potable water demands from an 
increasing population take their toll on water resources, better management and ways to store and recharge groundwater are paramount, and underground water storage could be a much-needed solution [11]. Groundwater depth is a critical feedback variable that determines vegetation dynamics [12]. Many studies have focused on the natural vegetation responses to groundwater change $[13,14]$ as a result of artificial watering in arid areas. Change in the groundwater table can influence the development and composition of vegetation, which in turn affects the fragile ecosystem $[15,16]$. Therefore, the successful conservation of riparian forests will require knowledge of groundwater and stream flow [17].

Direct infiltration and groundwater recharge in arid environments are relatively low due to the rarity of rainstorms, low mean average precipitation, and high potential evaporation; therefore, in many desert areas, direct rain infiltration is regarded as nonexistent [18]. Water resource management in arid environments currently rely on quantifying flood water infiltration and percolation, which recharges the shallow alluvial aquifers [5]. Flood water infiltrates ephemeral channels, recharging local and regional aquifers, and is the main water source in hyper-arid regions [1], while also being an important water source for mountain-front recharge and interbasin flow $[19,20]$. Furthermore, understanding and estimating the recharge from overbank floods is important [4] as the infiltrated flood water provides the water resources necessary for maintaining human settlements, riparian vegetation, and wildlife along the rivers. Therefore, an understanding of floods and their associated recharge of alluvial aquifers is crucial for better management of valuable water resources [1]. It is also important to characterize the flood by quantifying the water volume involved in the event and not only at the height of the flood. This can be done by measuring the flood discharge during, after, and before the event, as mentioned by Tazioli [6]. Managed aquifer recharge, a more scientific term for the process of purposefully refilling aquifers with surface water to more effectively manage water supply, is also being studied in Arizona using 19 recharge basins as part of the Tonopah Desert Recharge Project, where researchers allowed surface water to slowly refill the underlying aquifer and carefully monitored wells to measure its progress [11].

The episodic recharge of aquifers during overbank floods is one component of the water balance, and is distinct from bank storage [21-23] or river losses, but involves vertical infiltration from overbank flows. Long-term development and management of groundwater in arid regions, especially in alluvial aquifers, depends on the establishment of a balance between the amounts of recharge and withdrawal. To accomplish this goal, recharge components must be carefully assessed [24].

The flood water infiltration process and its effect on groundwater recharge were measured in field experiments and simulated in previous studies $[1,5,25]$. As the volume of recharge during flooding is highly variable between catchments, it is difficult to quantify in the field [26]. Lysimeters play an important role in the understanding of soil water dynamics and allow a better understanding of the role of soil in the regional water balance [27]. Therefore, a study to investigate the flood effect on groundwater using lysimeters may provide a better understanding of the dynamics of flood water recharge of groundwater.

The relationship between hydraulic conductivity and pressure head is highly non-linear, and the direct measurement of these properties in the laboratory, as well as in the field, is often time consuming and expensive [28]. Therefore, this study applied the Richards equation model to simulate the process of groundwater flood recharge. In addition, the numerical model that was applied also assisted in providing a better understanding of the processes regarding the flood water recharge of groundwater.

The Tarim River is the largest continental river in China. More than $90 \%$ of the existing floodplain forests along the Tarim River rely on floods [29], and these forests provide a wide range of ecosystem services and functions. Groundwater is the main water source to maintain the regeneration of natural vegetation [30-32]. Planned or controlled flooding is an effective method for rehabilitating rivers and reversing ecosystem degradation [33]. Historically, the Tarim River was a mobile stream before the new embankment project was established, and was dominated by trees of Populus euphratica that mainly relied on groundwater and flood water to survive and grow. However, a new embankment project reduced the natural river flooding of the Tarim River. To recover the degenerated natural vegetation, 
ecological water consumption was artificially regulated by an ecological gate in the Tarim River [34,35]. The purpose of the ecological gate was to provide river water (similar to natural floods before) to plants along the Tarim River. Ecological gates controlled the river flooding of the Tarim River. Artificial floods have been used in many regulated streams and rivers to maintain plant communities [36]. The planned overflow plays an important role in the maintenance of plant cover on the land adjacent to the Tarim River. Therefore, it was necessary to investigate the flood effect on the groundwater in floodplain soils.

Existing literature [12-14] has found that a groundwater depth required to maintain growing vegetation should be less than six meters in the low reaches of the Tarim River. However, the groundwater level is usually deeper than six meters, therefore impeding local vegetation growth [37]. Previous studies have investigated the effect of the Tarim Basin overflow on the ecological characteristics of riparian vegetation [10,38,39]. Li et al. [35] found that flood water could percolate into the floodplain soils due to a high infiltration rate. Other studies described in References $[10,13,40]$ reported that river floods contributed to a rise in the groundwater level in the floodplains of the Tarim River; however, the process of a flood affecting the groundwater was not clear. Previous studies have also shown that flooding could raise the groundwater table in low reaches of the Tarim River [31]; however, information on the relationship between the flood water depth and height of the groundwater rise is limited, where there is a lack of measurements and data about the relationship between the groundwater level and the flood height is unknown. As mentioned above, whether or not the height of groundwater rises due to flood recharge can reach an optimal groundwater table depth that could maintain natural vegetation survival [41] is of great concern in the inland rivers of arid regions.

Determining the relationship between the flood ponding depth and change in the groundwater table in the river floodplain of the Tarim River is critical in assessing the contribution of natural or artificial planned overflow to groundwater recharge. This study aims to (1) investigate the flood effect on groundwater using lysimeters and a numerical model; and (2) determine the relationship between the flood water depth and height of the groundwater rise.

\section{Materials and Methods}

\subsection{Study Area}

The study was conducted at the Akesu National Water Balance Station $\left(40.37^{\circ} \mathrm{N}, 80.45^{\circ} \mathrm{E}\right.$, $1028.0 \mathrm{~m}$ a.s.l.), located in the upper reach of the Tarim Basin in the Xinjiang Province of northwestern China (Figure 1). Mountains to the north, west, and east encompass the Tarim Basin, and the vast expanse of the Taklimakan Desert dominates much of the Basin.

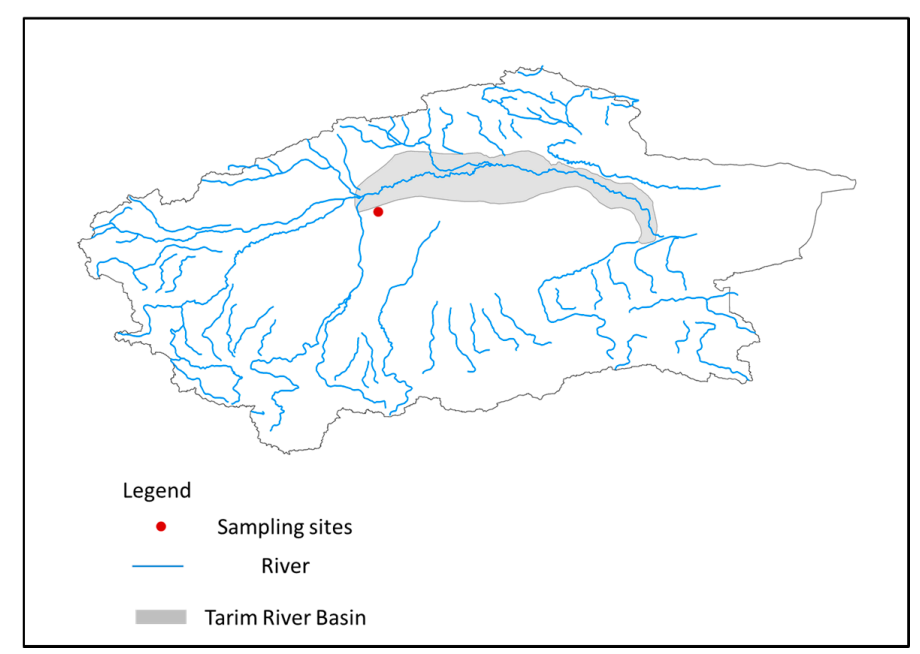

Figure 1. The schematic map in the Tarim River basin. 
The average annual precipitation ranges from $200 \mathrm{~mm}$ to $500 \mathrm{~mm}$ in the mountainous areas, from 50 to $80 \mathrm{~mm}$ on the side of the basin, and only $10 \mathrm{~mm}$ in the central basin. Precipitation increases from the west to the east in the plain area, and the temporal distribution of precipitation throughout the year is strongly heterogeneous. More than $80 \%$ of the total annual precipitation falls between May and October in the high flow season, and less than $20 \%$ of the total occurs from November to the following April [42]. Precipitation and temperature have been increasing persistently since the 1980s and significant increases in precipitation and temperature were observed after the 1990s [43]. The average annual runoff at the inlet is $3.98 \times 10^{10} \mathrm{~m}^{3}$ from 1957 to 2005 with snowmelt and precipitation in the surrounding high mountains as the main sources of water [44]. The groundwater depth was 2.53 to $2.06 \mathrm{~m}$ from 1958 to 2000 in the upper reaches, and $6.0 \mathrm{~m}$ to $9.87 \mathrm{~m}$ in the lower reaches of the Tarim River [45]. The population of this area was approximately 8.73 million in 2000 [46], and the major land uses were grassland, unused land and wetland, woodlands and croplands [47-49]. In the arid desert climate, desert shrubs and semi-shrubs are dominant while large herbaceous plants, shrubs and trees grow on the floodplains and low terraces along both riversides [50]. Woodlands are dominated by Populus euphratica, and major shrubs include Tamarix spp., Lycium ruthenicum, Halimodendron halodendron, etc., and herbs are mainly composed of Phragmites australis, Apocynum venetum, Alhagi sparsifolia, Karelinia caspica, Glycyrrhiza inflata, etc.

\subsection{Experiment Design}

The lysimeters were built at the Akesu National Water Balance Experiment Station. Three lysimeters (each $960 \mathrm{~mm}$ in diameter and $3700 \mathrm{~mm}$ in height) were separated by the observation well (1200 $\mathrm{mm}$ diameter and $3700 \mathrm{~mm}$ depth). The lysimeter casings were made of fiberglass reinforced plastic with a wall thickness of $12 \mathrm{~mm}$ (Figure 2), and each column was a lysimeter.
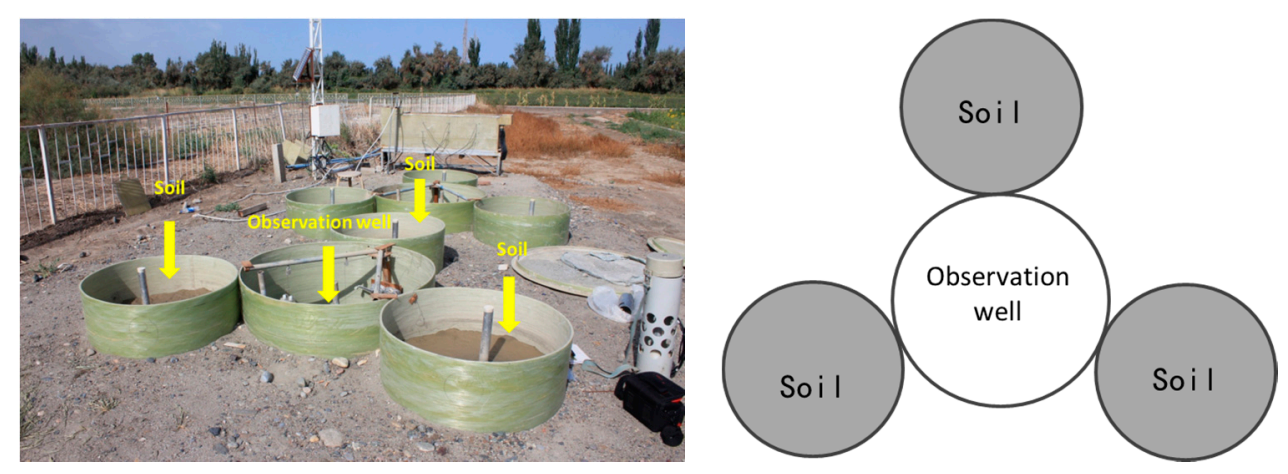

Figure 2. The lysimeters used in our experiment at the Aksu National Water Balance Station, Xinjiang, China.

The soil column was $3200 \mathrm{~mm}$ in height, and a filtering layer $(200 \mathrm{~mm})$ underlain by gravel was placed immediately beneath the water table at the bottom of each lysimeter to prevent fine particles of soil from flowing out during drainage, then the soil was packed with bulk density of $1.54 \mathrm{~g} \mathrm{~cm}^{-1}$ to $3200 \mathrm{~mm}$ from the surface of the gravel layer, which left $300 \mathrm{~mm}$ from the soil surface to the top of the lysimeter for ponding water. No plants were allowed to grow at the surfaces of the lysimeters. A porous pipe (20 mm in diameter) was installed in the layer of gravel which connected the water supply (Figure 3). The polymethyl methacrylate container served as a leveling container to obtain a constant water table before irrigation. The leveling container could be moved up and down by means of a pulley, which was fixed with a hand crank. Thus, the water table in the soil column was adjusted in correspondence to fluctuations of the groundwater table of the natural surroundings. A neutron probe tube made of aluminum with a diameter of $45 \mathrm{~mm}$ was installed in the center of each soil column. 


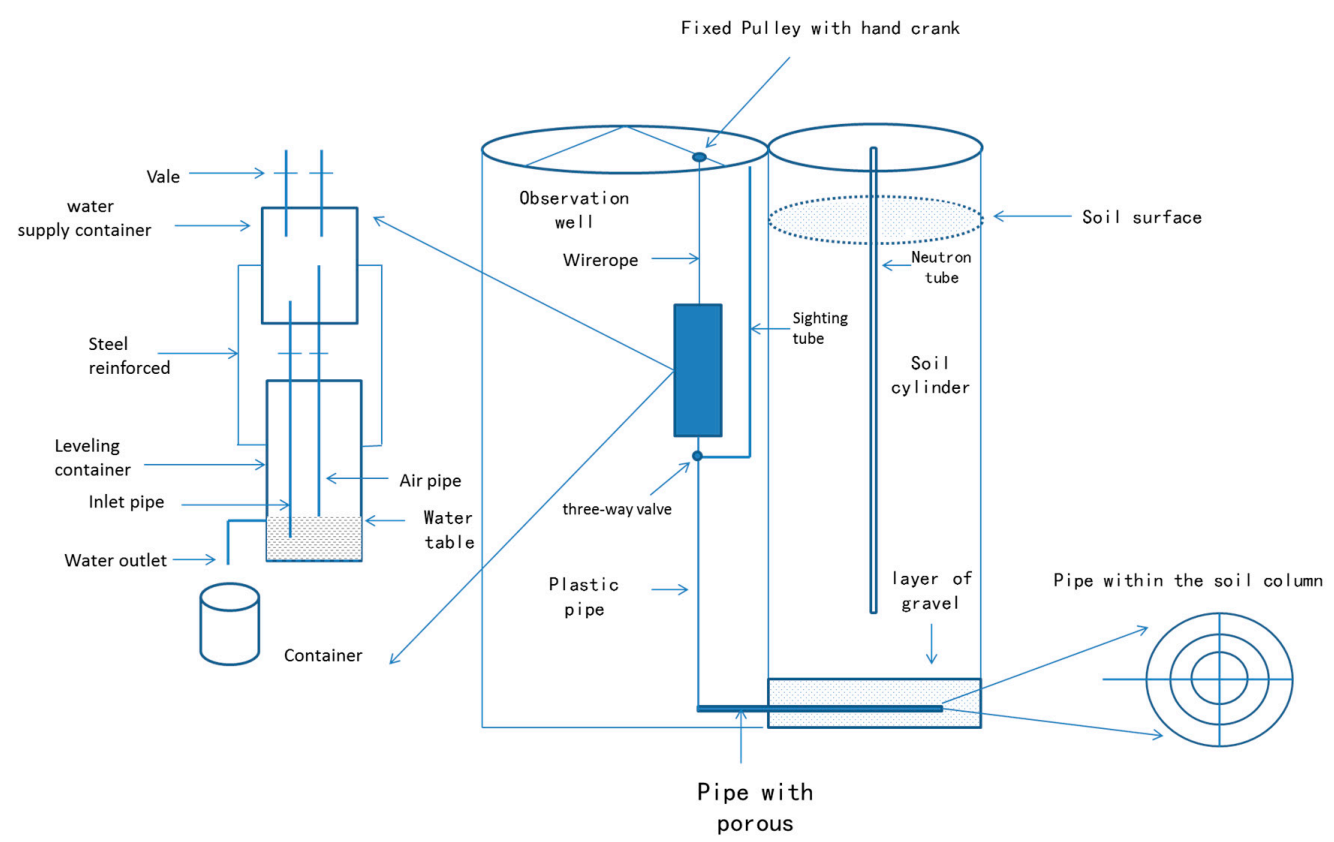

Figure 3. A diagram of the lysimeters with the capability to regulate the groundwater table.

The leveling container had a water outlet for collecting excess water in a percolation container that reached the bottom of the lysimeter due to water table recharge. The water table in the soil cylinder and a leveling container were maintained at the same level almost simultaneously. The groundwater control operation was similar to that described by Schendel [51]. The leveling container only adjusted the initial groundwater table and was closed by a three-way valve that was opened before the flood experiments. The groundwater level was measured by a sighting pipe.

The lysimeters were set in the pit using a crane. During the lysimeter construction, when a layer of approximately $0.3 \mathrm{~m}$ of soil was added, the soil was wetted to saturation. During the construction, soil moisture probes and the neutron probe access tube were installed. When all the soil layers were in place, up to the top of the soils, the excess water was allowed to drain to the bottom of the soil cylinder for two days and was pumped out with a vacuum pump.

Five flood depth treatments $(1,3,5$, and $10 \mathrm{~cm})$ and three initial groundwater level treatments $(200,250$, and $300 \mathrm{~cm})$ were performed. The soil moisture content was measured by a neutron probe (CNC503DR, Keyuan) at 14 depths (10, 30, 50, 70, 90, 110, 130, 150, 170, 190, 210, 230, 250, and $270 \mathrm{~cm}$ ). The soil surface was $0 \mathrm{~cm}$; the soil column bottom was $370 \mathrm{~cm}$.

\subsection{Soil Properties}

Silt loam soils $(0-100 \mathrm{~cm})$, which are the dominant soil type in the region, were collected from the upper reaches of Tarim River (Figure 1) and tested in the experiments. All soils samples were mixed and dried before placing into the lysimeters. The silt loam soil consisted of $41.53 \%$ sand and $53.62 \%$ silt, therefore the experiment represented most soils in the overflowing area of the Tarim River. The soils contained $4.094 \mathrm{~g} \mathrm{~kg}^{-1}$ soil organic matter, $0.267 \mathrm{~g} \mathrm{~kg}^{-1}$ total nitrogen, and $0.604 \mathrm{~g} \mathrm{~kg}^{-1}$ total phosphorus. The soils had a $\mathrm{pH}$ of 7.54 , an electric conductivity of $0.362 \mathrm{~ms} \mathrm{~cm}^{-1}$, and $1.053 \mathrm{~g} \mathrm{~kg}^{-1}$ solute salts. The saturated soil water content was $46 \%$, and the bulk density was $1.54 \mathrm{~g} \mathrm{~cm}^{-1}$. The soil water retention curve was determined (six replications) using a 15 Bar Pressure Plate Extractor (1500F1, Soil Moisture Equipment Corp, Santa Barbara, CA, USA), and the results are shown in Figure 4. Particle size distribution was determined using a Malvern Mastersizer S laser diffractometer (Malvern Instrument, Malvern, UK) that measures the volume percent of particles in 100 size classes from 0.02 to $2000 \mu \mathrm{m}$. 

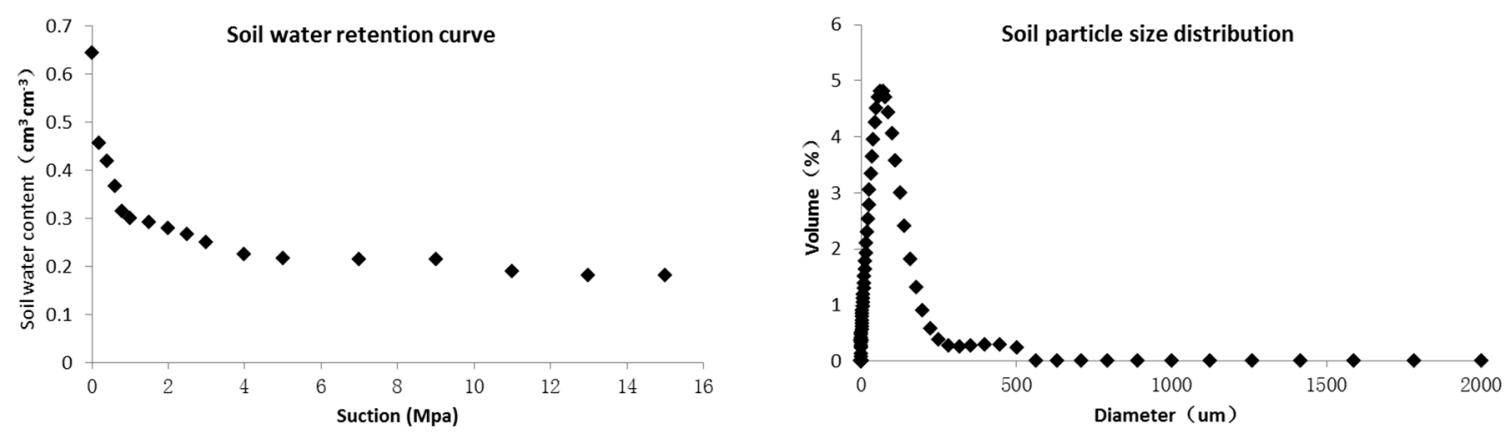

Figure 4. Soil water retention curve and particle size distribution of the soil used in the experiment.

\subsection{Numerical Simulation}

Soil water movement in the experimental field was simulated using the Richards model, which numerically solves the governing flow equation:

$$
\frac{\partial \theta}{\partial t}=\frac{\partial}{\partial z}\left[K\left(\frac{\partial h}{\partial z}+1\right)\right]
$$

where $\theta$ is the volumetric soil water content $\left(\mathrm{cm}^{3} \mathrm{~cm}^{-3}\right)$; h is the pressure head $(\mathrm{cm})$; and $k(\theta)$ is the unsaturated hydraulic conductivity function $\left(\mathrm{cm} \mathrm{day}^{-1}\right)$. The left-hand side of the Richards equation was expressed in terms of moisture content, rather than in terms of the hydraulic head. For this, we referred to the Hydrus-1D model [52].

Soil hydraulic properties were described using the van Genuchten-Mualem analytical functions in Reference [53]:

$$
\begin{gathered}
\theta(\mathrm{h})=\left\{\begin{array}{c}
\theta_{r}+\frac{\theta_{s}-\theta_{r}}{\left[1+|\alpha h|^{n}\right]^{m}} ; h<0 ; \\
\theta_{s} ; h \geq 0
\end{array}\right. \\
K(\theta)=K_{\mathrm{s}} S_{e}^{0.5}\left[1-\left(1-S_{e}^{1 / m}\right)^{m}\right]^{2} \\
S_{\mathrm{e}}=\frac{\left(\theta-\theta_{r}\right)}{\left(\theta_{s}-\theta_{r}\right)}, m=1-1 / n, n>1
\end{gathered}
$$

where $\theta_{S}$ is the saturated water content $\left(\mathrm{cm}^{3} \mathrm{~cm}^{-3}\right) ; \theta_{r}$ is the residual water content $\left(\mathrm{cm}^{3} \mathrm{~cm}^{-3}\right) ; K_{s}$ is the saturated hydraulic conductivity $\left(\mathrm{cm} \mathrm{day}^{-1}\right)$; and $\alpha$ and $\mathrm{n}$ are the shape parameters.

The soil water dynamics in the experimental field were evaluated as a one-dimensional movement. The depth of the simulation profile was $3.2 \mathrm{~m}$ (soil column was $3.2 \mathrm{~m}$ in height), which was discretized into a grid of $0.01 \mathrm{~m}$.

(1) Initial condition

The change of the soil moisture content with depth under the initial condition was defined as:

$$
\theta(z, 0)=\theta_{0}(z)
$$

where $\theta_{0}(z)$ is the initial measured soil water content.

(2) Upper boundary conditions

The atmospheric boundary condition was assigned at the upper boundary [52]:

$$
\frac{\partial \theta}{\partial t}=-\frac{\partial q}{\partial x}
$$

where $q$ is the surface water flux at the time of flooding. 
To simulate the level and flux of ponding water at the top of the lysimeter, the upper boundary was as follows:

$$
\left\{\begin{array}{l}
h(0, t)=z x j l(i), 0<z x j l(i) \\
z x j l(i)=z x j l(i-1)-\left(R S(i)+E_{0}\right) \times d t(i), z x j l(i)<Z X N L \\
z x j l(i)=\text { ZXNL,ZXNL } \leq \text { zxjl }(i)
\end{array}\right.
$$

where $z x j l(i)$ and $z x j l(i-1)$ are the depths of ponding at $i$ and $(i-1)(\mathrm{cm}) ; Z X N L$ is the retention capacity $(\mathrm{mm}) ; R S(i)$ is the infiltration intensity $\left(\mathrm{cm} \mathrm{min}^{-1}\right) ; E_{0}$ is the water surface evaporation intensity (mm) observed by evaporation pan (E601); and $d t(i)$ is the time step (min). Ponding may occur as ZXNL exceeded $z x j l(i)$, which might be caused by the retention from runoff under excess infiltration capacity. The infiltration process is considered as pressured infiltration when there is surface water in the soils, and the hydraulic head equal to the ponding water depth [54], otherwise ponding produces surface runoff when the ponding water depth reaches the maximum value, which is equal to the retention capacity.

(3) Bottom boundary conditions

The bottom boundary condition at $z=Z_{0}$ was defined as:

$$
\frac{\partial h}{\partial z}=1, z=Z_{0}
$$

(4) Evapotranspiration model and parameters

If no ponding water occurs on the soil surface, the solution methods were referred to those used for the Hydrus-1D model [52], where the evaporation intensity $E(t)$ [55] was calculated by Equation (9):

$$
\left\{\begin{array}{l}
E\left(h_{0}\right)=-E_{0} \exp \left(2 \times 10^{-4}\left(h_{0}-h_{e}\right)\right), h_{0}<h_{e} \\
E\left(h_{0}\right)=-E_{0}, h_{0}>h_{e}
\end{array}\right.
$$

where $h_{0}$ is the negative pressure at $10 \mathrm{~cm}$ below the soil surface $\left(\mathrm{mm} \mathrm{H}_{2} \mathrm{O}\right) ; h_{e}$ is the critical negative pressure equivalent to the negative pressure of the field capacity (with the negative pressure of the soils in this experiment being $-2580 \mathrm{~mm} \mathrm{H}_{2} \mathrm{O}$ at field capacity); $E_{p}$ is the potential evaporation intensity; and $E_{0}$ is the water surface evaporation intensity $(\mathrm{mm})$. The model parameters are shown in Table 1. Parameters Ks and $\theta_{s}$ were measured, while parameters $\theta_{r}, \alpha$, and $\mathrm{n}$ were estimated by the soil water retention curve. The length interval of the simulated domain was $1 \mathrm{~cm}$, and a variable time interval that was automatically adjusted in terms of the convergence of iterative process was used $(0.001 \mathrm{~d}-1 \mathrm{~d})$. The code was edited by Matlab 7.0 (Portola Valley, CA, USA) for Windows.

Table 1. Soil hydraulic parameters of the van Genuchten-Mualem model in the experiment.

\begin{tabular}{ccccc}
\hline $\begin{array}{c}\text { Residual Soil } \\
\text { Water Content }\end{array}$ & $\begin{array}{c}\text { Saturated Soil } \\
\text { Water Content }\end{array}$ & Parameter & Exponent & $\begin{array}{c}\text { Saturated Hydraulic } \\
\text { Conductivity }\end{array}$ \\
\hline$\theta_{r}(-)$ & $\theta_{S}(-)$ & $\alpha\left(\mathrm{cm}^{-1}\right)$ & $\mathrm{n}$ & $K_{s}\left(\mathrm{~cm} \cdot \mathrm{day}^{-1}\right)$ \\
0.16 & 0.48 & 0.0026 & 1.64 & 61.68 \\
\hline
\end{tabular}

\section{(5) Limiting assumption and uncertainty}

In operation, the model assumed that: (1) the soil properties were homogeneous; (2) soil was bare without a vegetation cover, and the plant root was sparse; (3) the study area was far away from the river so the increase in the groundwater table due to lateral water flow was neglected; (4) the soil water movement was assumed to occur in honogeneous media so the impact of soil macropore flow 
was neglected; and (5) the influence of ponding water on soil structure and porosity was neglected, and changes to the parameters of the VG model by ponding water pressure were not considered.

\section{Results and Discussion}

The experimental results showed that the flood water depth significantly contributed to groundwater recharge and that various flood water depths had different effects under different initial groundwater tables (Figure 5). Under flood water depths of 1, 3, 5 and $10 \mathrm{~cm}$, the groundwater table rose 15.1, $48.6,76.9$ and $142.5 \mathrm{~cm}$, respectively when the initial groundwater table was at $200 \mathrm{~cm}$; the groundwater table rose 9.5, 36.5, 69.5 and $108.1 \mathrm{~cm}$, respectively when the initial water table was at $250 \mathrm{~cm}$; and the groundwater table rose $0.0,23.7,64.6$ and $87.1 \mathrm{~cm}$, respectively, when the initial water table was at $300 \mathrm{~cm}$. When the flood water depth increased, the height of the groundwater table rise increased. It was found that there was a strong relationship between the flood water depth and height of the water table rise, and the determination coefficients $\left(R^{2}\right)$ was 0.997 when the initial groundwater table was at $200 \mathrm{~cm}, 0.967$ when the initial groundwater table was at $250 \mathrm{~cm}$, and 0.900 when the initial groundwater table was at $250 \mathrm{~cm}$.

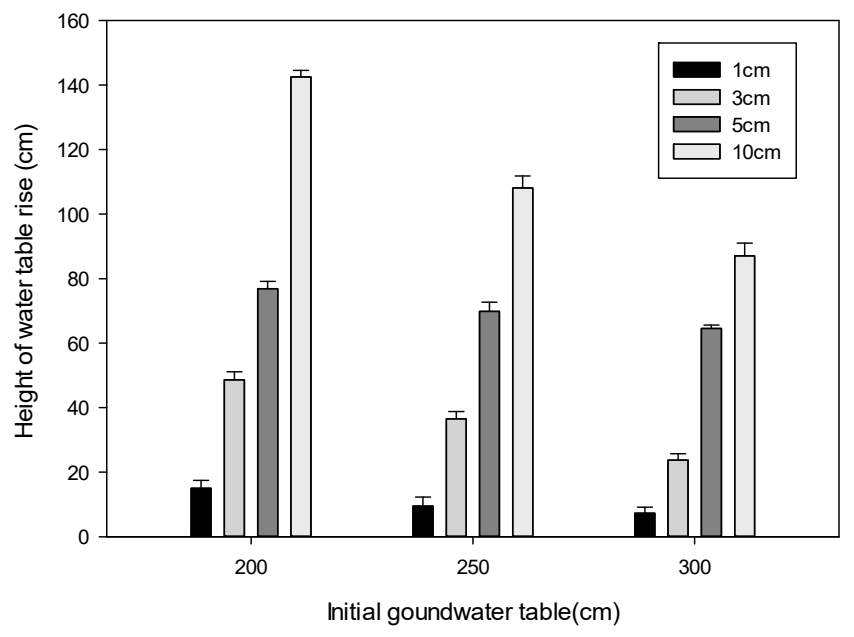

Figure 5. The height of the groundwater table rise under different initial depths of groundwater table and amount of flood.

Similar results were reported by Sorman and Abdulrazzak [24], who suggested that flood runoff volume and duration were the dominant factors influencing the cumulative infiltrated volume and recharge of shallow groundwater tables. Morin et al. [1] showed the importance of the role of large and medium floods in aquifer recharge; the relative contribution of high-magnitude floods to groundwater recharge also increased, whereas medium and small floods contributed relatively less. Lange [56] reported that high-magnitude floods were mostly significant for groundwater recharge under the Kuiseb River. The above-mentioned research was similar to our research results.

The slope of the relationship between the flood water ponding depth and height of the water table rise at the initial groundwater tables of 200, 250, and $300 \mathrm{~cm}$ were 13.99, 10.85, and 9.65, respectively. These results indicated that the height of the water table rise was closely related to flood water depth; if the initial water table was deeper, the variation in the depth of the water table rise was smaller. Sorman and Abdulrazzak [24] also reported that the relationship between the ground water recharge and flood inflow volume could be represented by linear regression equations, with the correlation coefficients of 0.76 , but the slope was 0.302 , which was still lower than the slope related to flood recharge infiltration in our research. Note that Sorman and Abdulrazzak [24] experiments were conducted under conditions of possible surface water runoff, while our experiments were conducted in lysimeters with ponding water, with no occurrence of outflow. 
A recharge process following a flood event is usually comprised of three processes stages: the rising process of the groundwater table; the peak part of the groundwater table; and the declining part or recession process [57]. Figure 6 clearly displays the temporal changes process of the water table; the groundwater table rises rapidly after flooding, reaching maximum values after 4.0-10.5 $\mathrm{h}$ with a mean value of $6.16 \mathrm{~h}$ (SE of $0.82 \mathrm{~h}$ ) for all tests, indicating that the groundwater responded quickly to floods in these experiments, which were consistent with results from Doble et al. [26]. Doble et al. [26] also reported that overbank flood recharge was distinct from hydrostatic loading (the pressure at any depth due to hydrostatic pressures), which is characterized by a rapid rise in groundwater. Dahan et al. [5] observed that a flood caused the water level to rise after $5.5 \mathrm{~h}$ and reached peak water level in the hyper-arid area of the Arava Valley, which is also in agreement with our research.
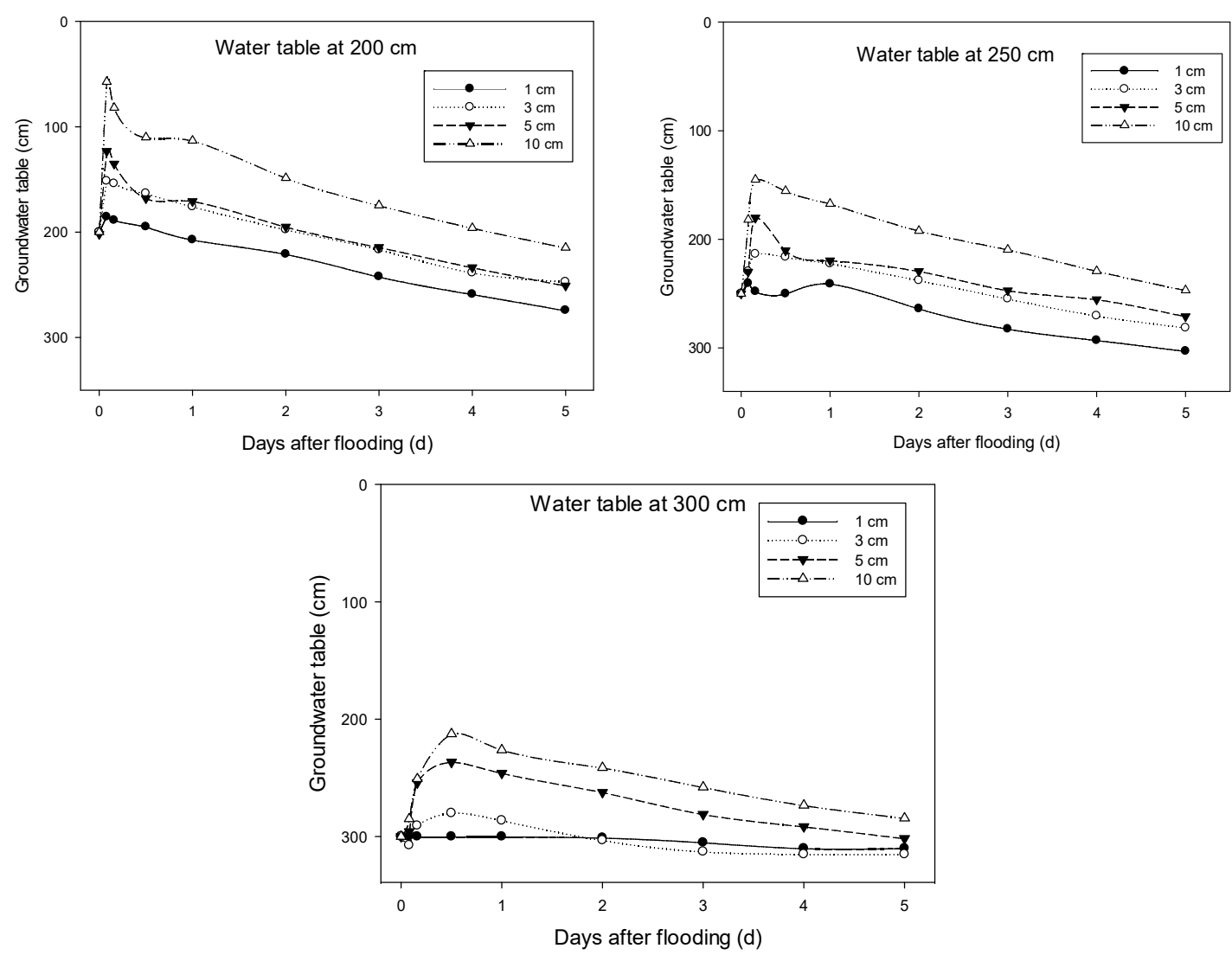

Figure 6. The response of the groundwater table to flood depth over time.

As soon as the flood ceased, the infiltration process stopped, the vadose zone was partially drained, and the groundwater level started to decrease toward a new water level that was higher than the initial one [58]. When the groundwater table reached a maximum value after a flood water recharge, the water table started falling due to evaporation, and the water falling velocity was significantly smaller than the water table rise velocity. In our experiment, even when the groundwater table was at a depth of $3.2 \mathrm{~m}$ (the highest groundwater table), evaporation was still present. This was the reason why the evaporation rate was much lower than the ponding water infiltration rate. The soil used in our experiment was a sandy loam with a high infiltration rate (saturated hydraulic conductivity was $61.68 \mathrm{~cm} \mathrm{~d}^{-1}$ ); however, the measured water surface evaporation rate ranged from 3.1 to $15.7 \mathrm{~mm} \mathrm{~d}^{-1}$, with a mean value of $6.3 \mathrm{~mm} \mathrm{~d}^{-1}$ during the experiment. Xu et al. [59] also reported that groundwater rise velocity was larger than the water falling velocity after flooding in the lower reaches of the Tarim River, and the water rise velocity was slower for deeper water levels, which was similar to our research results. 
If the initial groundwater table was deeper, the range of change in the groundwater table was smaller (Figure 5), which indicated that the flood ponding water had less impact on deeper groundwater tables. Wu et al. [57] discovered that when the groundwater table was shallow, flood water percolated into the groundwater relatively quickly, which was consistent with our results. For example, in our experiment, the elapsed time of the water table reaching peak water level was $3.6 \mathrm{~h}$ at an initial groundwater table depth of $200 \mathrm{~cm}$; however, it was $10.1 \mathrm{~h}$ at an initial groundwater table depth of $300 \mathrm{~cm}$.

When the groundwater table was very deep, the variations in the recharge rate became imperceptible [57]. Our results partly supported this conclusion; however, we observed that a relatively small amount of flood water still slightly recharged a deep groundwater table. For example, the deepest groundwater table was $3.0 \mathrm{~m}$ in our research, and if the flood water depth was $1 \mathrm{~cm}$, a rise in the groundwater table was not observed; however, if the flood ponding water was $10 \mathrm{~cm}$, a rise in height of $87.07 \mathrm{~cm}$ was measured. Though groundwater tables deeper than $3.0 \mathrm{~m}$ were not examined in our experiment, $\mathrm{Xu}$ et al. [59] reported that the groundwater table increased from 9.87 to $3.16 \mathrm{~m}$ after a flood in the Tarim River.

If the initial groundwater table was deeper and the water table drop was slower, it may have been due to less evaporation of the deeper water table. Warrick [60], Gardner and Fireman [61] and Thorburn et al. [62] found that the relationship between the depth of the groundwater table and the amount of evaporation from soils was an inverse power relationship, indicating that deeper groundwater tables had smaller water consumptions due to evaporation. This provided a good explanation as to why the deeper water tables had slower falling velocities. The water table fall was more rapid at the initial stage and then dropped slowly (Figure 5). This was explained by the fact that the water table was initially higher due to flood water recharge; in turn, the higher groundwater table experienced more evaporation, which contributed to the rapid falling; as a result, the groundwater table dropped to a deeper level, evaporation was reduced, and the groundwater falling velocity was slowed.

Dahan et al. [58] reported that the rising rates of the groundwater level were 1.38 and $1.4 \mathrm{~cm} \mathrm{~h}^{-1}$ for two floods in the Kuiseb River. Our results showed higher rising rates, which may be due to the fact that our experiments were conducted in lysimeters containing homogeneous soil and water movement was a one-dimensional process with homogeneous soil. Dahan et al. [58] conducted their experiments under larger-scale field conditions, which were likely affected by lateral flow within a layered profile of alluvial deposits with possible preferential flow.

Numerical simulations based on a system of Equations (1)-(9) showed good agreement between the simulated and measured groundwater levels with an $R^{2}$ and an RMSE of 0.87 and $63.91 \mathrm{~cm}$, respectively, which suggested a high consistency between the simulated and experimentally observed processes (Figure 7).

Similar to our results, Rennolls et al. [63,64] and Barnes et al. [65] employed regression models to estimate the infiltration recharge of groundwater at relatively shallow water tables. The rise in the height of the groundwater table-as affected by flood water depths under six initial groundwater tables-and four initial soil water contents were simulated, and the results are shown in Figure 8. By considering the influence of various hydrological characteristics, regression equations have been suggested to estimate the groundwater recharge [24]. Therefore, a regression equation between the initial groundwater table, initial soil water content, flood water depth and water table rise was fitted using the results of the numerical model:

$$
H=-10.639 H_{0}+23.552 w_{0}+23.989 h-90.439,(H>0)
$$

where $H$ is the groundwater height rise; $H_{0}$ is the initial groundwater depth $(\mathrm{cm}) ; w_{0}$ is the initial soil water content $(\mathrm{cm})$; and $h$ is the flood water depth $(\mathrm{cm})$. 


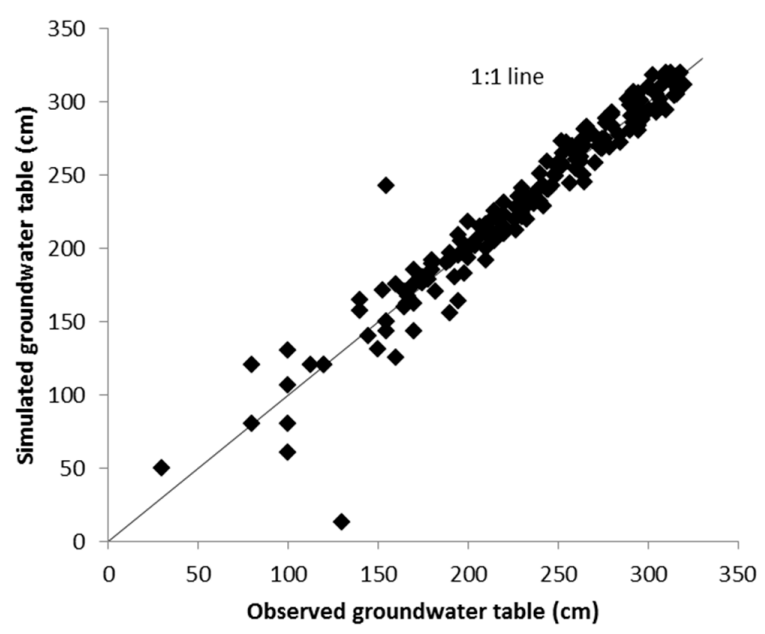

Figure 7. Observed vs. simulated ground water table and 1:1 line.
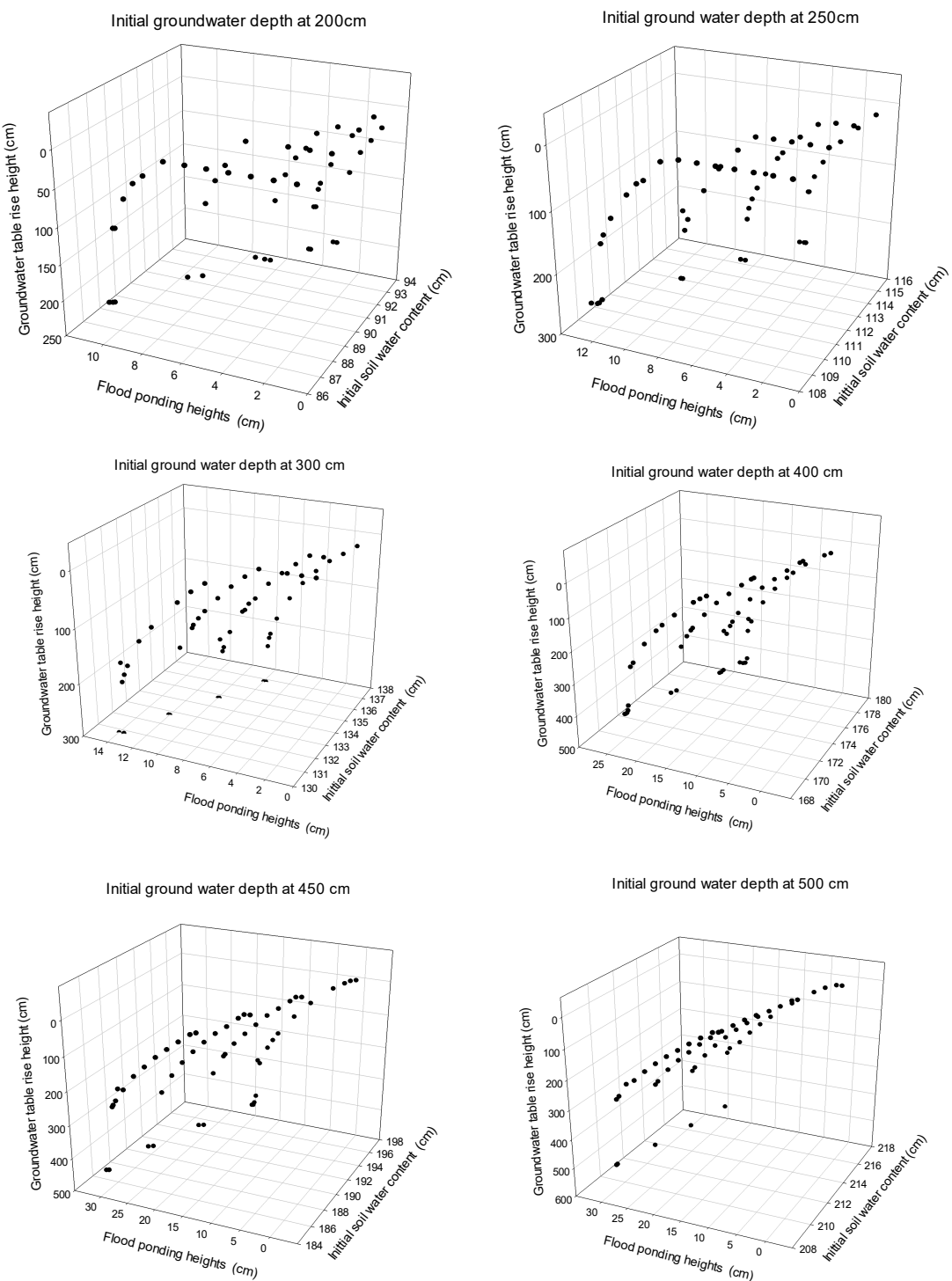

Figure 8. Numerical simulation results of the groundwater table rise height as affected by flood ponding heights under different initial groundwater table depth and soil water content. 
The $R^{2}$ and RMSE values were 0.789 and $80.80 \mathrm{~cm}$, respectively. Sorman and Abdulrazzak [24] reported that larger contributions may occur as a result of high initial soil moisture content accumulated from sequences of flood events and a shallow groundwater table. Our regression equation showed that $H$ was positively correlated to $h$ and $w_{0}$, but was negatively correlated to $H_{0}$; therefore, our results fully agreed with this conclusion.

The frequency of overbank flooding also determines the significance of this recharge to the water balance [26]. When planning schemes of groundwater recharge, it is especially important to know the maximum volume of water that can recharge the groundwater in a given period of time [7]. This is of great concern in planned or regulated flooding (e.g., ecological gates) for determining the time of artificial watering and the amount of artificial flooding in the Tarim River. Therefore, the artificial watering time interval was also considered in our study. The relationship between the flood time interval, initial groundwater table, initial soil water content, flood water amount and depth of the water table rise was fitted using numerical model results:

$$
H=-0.168 H_{0}+2.532 w_{0}+1.415 h-0.990 d t-14.131, \quad(H>0)
$$

where $d t$ is the time interval (day). The $R^{2}$ and RMSE values were 0.892 and $115.964 \mathrm{~cm}$, respectively.

Our results were obtained on a silt loam with a high infiltration rate; Li et al. [35] reported that the infiltration rate was high in the entire floodplain of the Tarim River. Glenn et al. [66] found soils that contained $49.23 \%$ sand and $14.23 \%$ clay in a US riparian zone; Ghazavi et al. [25] observed soils composed of $62.05 \%$ sand and $8.17 \%$ clay in a floodplain in Iran; and Dahan et al. [58] reported soils consisting of $90.82 \%$ sand and $1.80 \%$ clay at a depth of 0-6 $\mathrm{m}$ in Israel. In general, soils with low clay and high sand proportions showed high infiltration rates [67]. All these reports suggested that soils with high infiltration rates were common in hyper-arid river floodplains. Our model demonstrated a good performance for sandy loam in the Tarim River; however, as this model was applied to other soil types and regions, it required local input parameters $\left(\theta_{s}, \theta_{r}, K_{s}, \alpha, \mathrm{n}\right)$ of the VG model. If soil texture was different across the various layers, those parameters were measured in the different layers, and all input parameters were associated with given soil layers. A fixed space interval was recommended (e.g., $1-3 \mathrm{~cm}$ ). In contrast, a variable time interval that could be automatically adjusted in terms of the convergence of the iterative process was suggested. Therefore, our research results could serve as a reference for other floodplains in hyper-arid regions across the world.

\section{Conclusions}

We studied flood water infiltration and groundwater recharge using lysimeters and numerical models in the floodplains of the Tarim River, China. The different flood water depths resulted in different heights of the groundwater table rise under different initial groundwaters. It was found that there was a strong relationship between the flood water ponding depth and the height of the water table rise. The groundwater responded quickly to flood water, and its falling velocity was significantly less than its water rise velocity. If the initial groundwater table was deeper, the range of change in the groundwater table was smaller.

Acknowledgments: This research was supported by the National Natural Science Foundation of China (Grant No. 41571035) and the Youth Innovation Promotion Association CAS (2017477).

Author Contributions: “Xinhu Li and Gary Feng conceived and designed the experiments; Xinhu Li performed the experiments; Xiaoyu Pi and Congbao Xie analyzed the data; Xinhu Li contributed materials; Guohua Zhang wrote the paper." Authorship must be limited to those who have contributed substantially to the work reported.

Conflicts of Interest: The authors declare no conflict of interest. 


\section{References}

1. Morin, E.; Grodek, T.; Dahan, O.; Benito, G.; Kulls, C.; Jacoby, Y.; Van Langenhove, G.; Seely, M.; Enzel, Y. Flood routing and alluvial aquifer recharge along the ephemeral arid Kuiseb River, Namibia. J. Hydrol. 2009, 368, 262-275. [CrossRef]

2. Kowsar, A. Desertification control floodwater spreading in Iran. Unasylva 1992, 43, 27-30.

3. Unger, I.M.; Motavalli, P.P.; Muzika, R.M. Changes in soil chemical properties with flooding: A field laboratory approach. Agric. Ecosyst. Environ. 2009, 131, 105-110. [CrossRef]

4. Workman, S.R.; Serrano, S.E. Recharge to alluvial valley aquifers from overbank flow and excess infiltration. J. Am. Water Resour. Assoc. 1999, 35, 425-432. [CrossRef]

5. Dahan, O.; Shani, Y.; Enzel, Y.; Yechieli, Y.; Yakirevich, A. A direct measurements of floodwater infiltration into shallow alluvial aquifers. J. Hydrol. 2007, 344, 157-170. [CrossRef]

6. Tazioli, A.; Mattioli, A.; Nanni, T.; Vivalda, P.M. Natural Hazard Analysis in the Aspio Equipped Basin. In Engineering Geology for Society and Territory_Volume 3; Springer: Cham, Switzerland, 2015; pp. 431-435.

7. Hendrickx, J.M.H.; Khan, A.S.; Bannink, M.H.; Birch, D.; Kidd, C. Numerical-analysis of groundwater recharge through stony soils using limited data. J. Hydrol. 1991, 127, 173-192. [CrossRef]

8. Vivalda, P.; Tazioli, A.; Nanni, T.; Mussi, M. The Mt Conero limestone ridge: The contribution of stable isotopes to the identification of the recharge area of aquifers. Ital. J. Geosci. 2017, 136, 1-31.

9. Cervi, F.; Ronchetti, F.; Doveri, M.; Mussi, M.; Marcaccio, M.; Tazioli, A. The use of stable water isotopes from rain gauges network to define the recharge areas of springs: Problems and possible solutions from case studies from the northern Apennines. GEAM Geoing. Ambient. E Mineraria 2016, 149, 19-26.

10. Yu, P.; Xu, H.; Ye, M.; Liu, S.; Gong, J.; An, H.; Fu, J. Effects of ecological water conveyance on the ring increments of populus euphratica in the lower reaches of Tarim River. J. For. Res.-Jpn. 2011, 17, 413-420. [CrossRef]

11. Growing Georgia, A.N. Creating Floods to Refill Aquifers: How It Works. Available online: http://growinggeorgia.com/features/2017/01/creating-floods-refill-aquifers-how-it-works/?utm_source= Growing+Georgia\&utm_campaign=0406fa2f0c-growinggeorgia-daily_newsletter\&utm_medium=email\&utm_ term=0_4643f190f7-0406fa2f0c-296616933 (accessed on 20 January 2017).

12. Han, M.; Zhao, C.Y.; Feng, G.; Shi, F.Z. Bayesian inference of the groundwater depth threshold in a vegetation dynamic model: A case study, lower reach, Tarim River. Quatern. Int. 2015, 380, 207-215. [CrossRef]

13. Chen, Y.N.; Li, W.H.; Xu, C.C.; Ye, Z.X.; Chen, Y.P. Desert riparian vegetation and groundwater in the lower reaches of the Tarim River basin. Environ. Earth Sci. 2015, 73, 547-558. [CrossRef]

14. Chen, Y.; Chen, Y.; Xu, C.; Li, W. The effects of groundwater depth on water uptake of populus euphratica and tamarix ramosissima in the hyperarid region of northwestern China. Environ. Sci. Pollut. Res. Int. 2016, 23, 17404-17412. [CrossRef] [PubMed]

15. Lammerts, E.J.; Maas, C.; Grootjans, A.P. Groundwater variables and vegetation in dune slacks. Ecol. Eng. 2001, 17, 33-47. [CrossRef]

16. Doble, R.; Simmons, C.; Jolly, I.; Walker, G. Spatial relationships between vegetation cover and irrigation-induced groundwater discharge on a semi-arid floodplain, Australia. J. Hydrol. 2006, 329, 75-97. [CrossRef]

17. Snyder, K.A.; Williams, D.G. Water sources used by riparian trees varies among stream types on the San Pedro River, Arizona. Agric. For. Meteorol. 2000, 105, 227-240. [CrossRef]

18. Scanlon, B.R. Evaluation of Methods of Estimating Recharge in Semiarid and Arid Regions in the Southwestern US; AGU: Washington, DC, USA, 2004.

19. Stonestrom, D.A.; Constantz, J.; Ferré, T.P.A.; Leake, S.A. Ground-Water Recharge in the Arid and Semi Arid Southwestern United States; U.S. Geological Survey: Menlo Park, CA, USA, 2007.

20. Hagedorn, B. Hydrochemical and $14 \mathrm{C}$ constraints on groundwater recharge and interbasin flow in an arid watershed: Tule Desert, Nevada. J. Hydrol. 2015, 523, 297-308. [CrossRef]

21. Cooper, H.H.; Rorabaugh, M.I. Ground-Water Movements and Bank Storage due to Flood Stages in Surface Streams; Water-Supply Paper 1536-J; U.S. Government Printing Office: Washington, DC, USA, 1963; pp. 343-366.

22. Hall, F.R.; Moench., A.F. Application of the convolution equation to stream-aquifer relationships. Water Resour. Res. 1972, 8, 487-493. [CrossRef]

23. McCallum, J.L.; Cook, P.G.; Brunner, P.; Berhane, D. Solute dynamics during bank storage flows and implications for chemical base flow separation. Water Resour. Res. 2010, 46. [CrossRef] 
24. Sorman, A.U.; Abdulrazzak, M.J. Infiltration-recharge through wadi beds in arid regions. Hydrol. Sci. J. 1993, 38, 173-186. [CrossRef]

25. Ghazavi, R.; Vali, A.; Eslamian, S. Impact of flood spreading on infiltration rate and soil properties in an arid environment. Water Resour. Manag. 2010, 24, 2781-2793. [CrossRef]

26. Doble, R.C.; Crosbie, R.S.; Smerdon, B.D.; Peeters, L.; Cook, F.J. Groundwater recharge from overbank floods. Water Resour. Res. 2012, 48. [CrossRef]

27. Goss, M.J.; Ehlers, W. The role of lysimeters in the development of our understanding of soil water and nutrient dynamics in ecosystems. Soil Use Manag. 2009, 25, 213-223. [CrossRef]

28. Kumar, S.; Sekhar, M.; Reddy, D.V.; Kumar, M.S.M. Estimation of soil hydraulic properties and their uncertainty: Comparison between laboratory and field experiment. Hydrol. Process. 2010, 24, 3426-3435. [CrossRef]

29. Song, Y.D.; Fan, Z.L.; Lei, Z.D. Research on Water Resources and Ecology of the Tarim River, China; Xinjiang Peoples Press: Urumqi, China, 2000.

30. Cui, Y.; Shao, J. The role of ground water in arid/semiarid ecosystems, northwest China. Ground Water 2005, 43, 471-477. [CrossRef] [PubMed]

31. Chen, Y.N.; Chen, Y.P.; Xu, C.C.; Ye, Z.X.; Li, Z.Q.; Zhu, C.G.; Ma, X.D. Effects of ecological water conveyance on groundwater dynamics and riparian vegetation in the lower reaches of Tarim River, China. Hydrol. Process. 2010, 24, 170-177. [CrossRef]

32. Cao, D.; Li, J.; Huang, Z.; Baskin, C.C.; Baskin, J.M.; Hao, P.; Zhou, W.; Li, J. Reproductive characteristics of a populus euphratica population and prospects for its restoration in China. PLoS ONE 2012, 7, e39121. [CrossRef] [PubMed]

33. Wuethrich, B. Ecology-deliberate flood renews habitats. Science 1996, 272, 344-345. [CrossRef]

34. Gabrielie, L.K.; Friedman, J.M.; Beatty, S.W. Delayed effects of flood control on a flood-dependent riparian forest. Ecol Appl. 2005, 15, 1019-1035.

35. Li, X.; Feng, G.; Zhao, C.; Shi, F. Characteristics of soil infiltration in the Tarim River floodplain. Environ. Earth Sci. 2016, 75, 782. [CrossRef]

36. Jansson, R.; Zinko, U.; Merritt, D.M.; Nilsson, C. Hydrochory increases riparian plant species richness: A comparison between a free-flowing and a regulated river. J. Ecol. 2005, 93, 1094-1103. [CrossRef]

37. Jiang, L.; Chen, X.; Bao, A. Analysis on the changing dynamics of groundwater level in the lower reaches of the Tarim River, Xinjiang. Arid Land Geogr. 2005, 28, 33-37.

38. Liu, D.; Tian, F.; Hu, H.; Lin, M.; Cong, Z. Ecohydrological evolution model on riparian vegetation in hyperarid regions and its validation in the lower reach of Tarim River. Hydrol. Process. 2012, 26, 2049-2060. [CrossRef]

39. Hao, X.M.; Li, W.H.; Huang, X.; Zhu, C.G.; Ma, J.X. Assessment of the groundwater threshold of desert riparian forest vegetation along the middle and lower reaches of the Tarim River, China. Hydrol. Process. 2010, 24, 178-186. [CrossRef]

40. Aishan, T.; Halik, U.; Cyffka, B.; Kuba, M.; Abliz, A.; Baidourela, A. Monitoring the hydrological and ecological response to water diversion in the lower reaches of the Tarim River, northwest China. Quatern. Int. 2013, 311, 155-162. [CrossRef]

41. Chen, Y.N.; Wang, Q.A.; Li, W.H.; Ruan, X.; Chen, Y.P.; Zhang, L.H. Rational groundwater table indicated by the ecophysiological parameters of the vegetation: A case study of ecological restoration in the lower reaches of the Tarim River. Chin. Sci. Bull. 2006, 51, 8-15. [CrossRef]

42. Chen, Y.N.; Ye, Z.X.; Shen, Y.J. Desiccation of the Tarim River, Xinjiang, China, and mitigation strategy. Quatern. Int. 2011, 244, 264-271. [CrossRef]

43. Zhang, Q.; Gu, X.H.; Singh, V.P.; Sun, P.; Chen, X.H.; Kong, D.D. Magnitude, frequency and timing of floods in the Tarim River basin, China: Changes, causes and implications. Glob. Planet Chang. 2016, 139, 44-55. [CrossRef]

44. Chen, Y.; Xu, C.; Chen, Y.; Liu, Y.; Li, W. Progress, challenges and prospects of eco-hydrological studies in the Tarim River basin of Xinjiang, China. Environ. Manag. 2013, 51, 138-153. [CrossRef] [PubMed]

45. Hao, X.; Chen, Y.; Li, W. The driving forces of environmental change during the last 50 years in the Tarim River basin. Acta Geogr. Sin. 2006, 61, 262-272.

46. Yang, J.; Guan, X.; Li, X.; Wen, Q.; Zhang, F. Study on the relations between the lucc and demographic factors in the past 10 years of Tarim River basin. J. Arid Land Resour. Environ. 2006, 20, 114-117. 
47. Zhao, R.; Chen, Y.; Shi, P.; Zhang, L.; Pan, J.; Zhao, H. Land use and land cover change and driving mechanism in the arid inland river basin: A case study of Tarim River, Xinjiang, China. Environ. Earth Sci. 2012, 68, 591-604. [CrossRef]

48. Li, X.; Feng, G.; Sharratt, B.S.; Zheng, Z.; Pi, H.; Gao, F. Soil wind erodibility based on dry aggregate-size distribution in the Tarim Basin. Soil Sci. Soc. Am. J. 2014, 78, 2009. [CrossRef]

49. Li, X.; Feng, G.; Sharratt, B.; Zheng, Z. Aerodynamic properties of agricultural and natural surfaces in northwestern Tarim Basin. Agric. For. Meteorol. 2015, 204, 37-45. [CrossRef]

50. Xu, H.L.; Ye, M.; Li, J.M. The ecological characteristics of the riparian vegetation affected by river overflowing disturbance in the lower Tarim River. Environ. Geol. 2009, 58, 1749-1755. [CrossRef]

51. Schendel, U. A newly developed groundwater lysimeter for measuring evapotranspiration from different groundwater levels in a small catchment area of the north german coastal region. IAHS Publ. 1971, 96, 53-59.

52. Simunek, J.; Van Genuchten, M.T.; Sejna, M. The Hydrus-1D Software Package for Simulating the One-Dimensional Movement of Water, Heat, Andmultiple Solutes in Variably-Saturated Media; Version 3.0; Department of Environmental Sciences: Riverside, CA, USA, 2005.

53. Van Genuchten, M.T. A closed-form equation for predicting the hydraulicconductivity of unsaturated soils. Soil Sci. Soc. Am. J. 1980, 44, 892-898. [CrossRef]

54. Nieber, J.L.; Walter, M.F. Two-dimensional soil-moisture flow in a sloping rectangular region-experimental and numerical-studies. Water Resour. Res. 1981, 17, 1722-1730. [CrossRef]

55. Bernard, R.; Vauclin, M.; Vidal-Madjar, D. Possible use of active microwave remote sensing data for prediction of regional evaporation by numerical simulation of soil water movement in the unsaturated zone. Water Resour. Res. 1981, 17, 1603-1610. [CrossRef]

56. Lange, J. Dynamics of transmission losses in a large arid stream channel. J. Hydrol. 2005, 306, 112-126. [CrossRef]

57. Wu, J.Q.; Zhang, R.D.; Yang, J.Z. Estimating infiltration recharge using a response function model. J. Hydrol. 1997, 198, 124-139. [CrossRef]

58. Dahan, O.; Tatarsky, B.; Enzel, Y.; Kulls, C.; Seely, M.; Benito, G. Dynamics of flood water infiltration and ground water recharge in hyperarid desert. Ground Water 2008, 46, 450-461. [CrossRef] [PubMed]

59. Xu, H.; Chen, Y.; Li, W. Study on response of groundwater after ecological water transport at the lower reaches of the Tarim River. Res. Environ. Sci. 2003, 16, 19-22.

60. Warrick, A.W. Additional solutions for steady-state evaporation from a shallow-water table. Soil Sci. 1988, 146, 63-66. [CrossRef]

61. Gardner, W.R.; Fireman, M. Laboratory studies of evaporation from soil columns in the presence of a water table. Soil Sci. 1958, 85, 244-249. [CrossRef]

62. Thorburn, P.J.; Hatton, T.J.; Walker, G.R. Combining measurements of transpiration and stable isotopes of water to determine groundwater discharge from forests. J. Hydrol. 1993, 150, 563-587. [CrossRef]

63. Rennolls, K.; Carnell, R.; Tee, V. A descriptive model of the relationship between rainfall and soil-water table. J. Hydrol. 1980, 47, 103-114. [CrossRef]

64. Viswanathan, M.N. Recharge characteristics of an unconfined aquifer from the rainfall water-table relationship. J. Hydrol. 1984, 70, 233-250. [CrossRef]

65. Barnes, C.J.; Jacobson, G.; Smith, G.D. The distributed recharge mechanism in the Australian arid zone. Soil Sci. Soc. Am. J. 1994, 58, 31-40. [CrossRef]

66. Glenn, E.P.; Morino, K.; Nagler, P.L.; Murray, R.S.; Pearlstein, S.; Hultine, K.R. Roles of saltcedar (Tamarix spp.) and capillary rise in salinizing a non-flooding terrace on a flow-regulated desert river. J. Arid Environ. 2012, 79, 56-65. [CrossRef]

67. Saxton, K.E.; Rawls, W.J. Soil water characteristic estimates by texture and organic matter for hydrologic solutions. Soil Sci. Soc. Am. J. 2006, 70, 1569-1578. [CrossRef]

(C) 2017 by the authors. Licensee MDPI, Basel, Switzerland. This article is an open access article distributed under the terms and conditions of the Creative Commons Attribution (CC BY) license (http:/ / creativecommons.org/licenses/by/4.0/). 